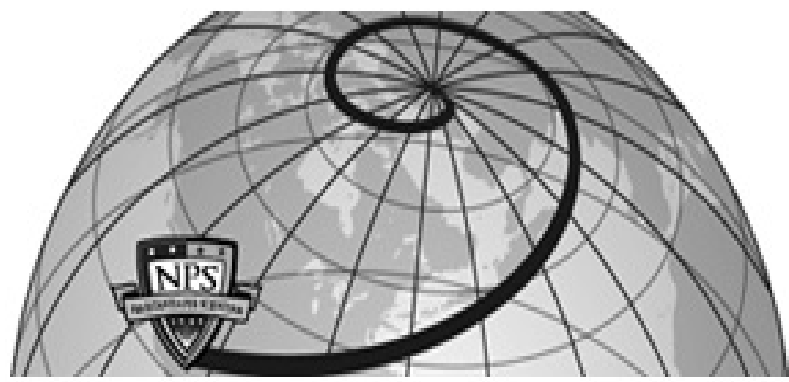

Calhoun: The NPS Institutional Archive DSpace Repository

\title{
The Role of Foreign Aid in the War on
}

Terrorism: Examples from Pakistan

Looney, R.E.

Looney, R.E., "The Role of Foreign Aid in the War on Terrorism: Examples from Pakistan," Political Crossroads 10/11, 2003/04, pp. 5-18.

https://hdl.handle.net/10945/40486

This publication is a work of the U.S. Government as defined in Title 17, United States Code, Section 101. Copyright protection is not available for this work in the United States.

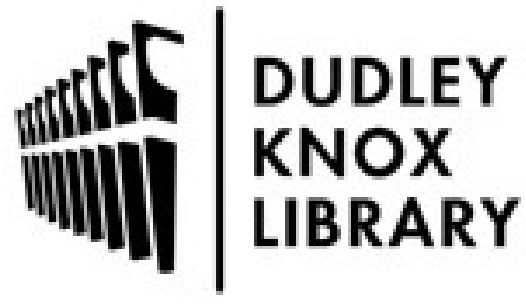

http://www.nps.edu/library
Calhoun is the Naval Postgraduate School's public access digital repository for research materials and institutional publications created by the NPS community. Calhoun is named for Professor of Mathematics Guy K. Calhoun, NPS's first appointed -- and published -- scholarly author.

Dudley Knox Library / Naval Postgraduate School 411 Dyer Road / 1 University Circle Monterey, California USA 93943 


\title{
The Role of Foreign Aid in the War on Terrorism: Examples From.Pakistan
}

\section{Robert Looney}

Naval Postgraduate School, Monterey

\begin{abstract}
The United States and its partners in the war on terrorism have respond ed to the terrorist attacks with a three-pronged strategy - short run military, medium term aid to vulnerable countries and groups, and longer term assistance programs that directly focus on the sources of terrorist motivation. Using Pakistan as a case study, it appears that the best way to implement the medium and longer term phases are assistance for education reform in the medium term, with the focus on institutional reform, and governance strengthening in the longer term. In most cases, grants are superior to aid in assuring effective and efficient implementation of the country's assistance related programs.
\end{abstract}

Keywords: terrorism, Foreign Aid, Pakistan, education reform, economic development

\section{Introduction}

In the Autumn of 2001, as United States troops launched their attack on Afghanistan's ruling Taliban, a battle of an entirely different sort was being planned in Washington. This campaign did not receive as much attention, but it was no less important, because it involved winning new allies in the war on terrorism with humanitarian relief for millions of refugees, and financial assistance for eradicating poverty through higher rates of economic growth in key regional countries.

The events of September 11 made it painfully clear that the political, social and economic problems of other countries have a direct impact on American national security. The United States was attacked by a terrorist organization that in large part has had great success in recruiting new members in nations which offer young men little political voice and limitéd economic opportunity. 
With this in mind the United States and its coalition partners have responded to the terrorist attacks with a three-pronged strategy short run military, medium term aid to vulnerable countries and groups and longer term assistance programs that directly focus on the sources of terrorist motivation. The first task has been generally successfully completed while the second is only in the initial stages of implementation. In all likelihood however these initial successes must also carry to the second and third medium - to longer-term strategies to assure the ultimate defeat of $\mathrm{Al}$ Qaeda and like-minded groups.

\section{Initial Aid Response}

Prior to the September 11 terrorist attacks, the Administration's top foreign aid initiatives for the 2002 fiscal year had been combating the spread of HIV/AIDS and other infectious diseases, fighting poverty, broadening the public/private partnership in aid programming, and expanding the counter-narcotics campaign in the Andean region. With the focus now on anti-Terrorism measures, these issues have had much less of a priority.

A main concern from the beginning was Pakistan which borders Afghanistan's entire southern rim and contains critical access routes to the country. Virtually all US aid to the country had been cut off after the Pakistanis revealed they had conducted nuclear weapons tests in 1998 .

To enlist Pakistan's assistance in fighting terrorism, the Bush administration asked (September 22) Congress for blanket authority to wave economic sanctions against countries whose help is needed in the anti-terror coalition. Congress quickly granted a limited form of such authority. Four days later the International Monetary Fund, where the US has the largest share of votes, approved a $\$ 135$ million loan for Pakistan even though the country was in arrears on servicing its $\$ 37$ billion national debt. The Treasury Department then announced it would ease terms on $\$ 379$ million of Pakistan's debt to the United States, setting the stage for other nations to follow.

On October 15 in Islamabad, the United States announced that it would provide $\$ 600$ million in aid to the country in fiscal year 2002, a figure that later rose to $\$ 673$ million. On November 10 , President Bush said that long-term aid for Pakistan could total as much as one billion dollars. The funds for the Bush administration's foreign aid initiatives in the immediate aftermath of September 11 came from the $\$ 40$ billion supplemental appropriations bill Congress passed on 
September 18, 2002. The administration quickly pulled together a $\$ 1.06$ billion aid package out of those funds, covering the aid packages for Afghanistan and Pakistan, and millions more for the four former Soviet states of Afghanistan's northern rim: Turkmenistan, Uzbekistan, Kyrgyzstan and Tajikistan:

\section{United States Aid Allocation for FY 2002 (million\$)}

\begin{tabular}{lll}
\hline Country & Before September 11 & After \\
Afghanistan & $\$ 2.9$ & $\$ 280.9$ \\
Pakistan & 10.5 & 683.5 \\
Kazakhstan & 51.5 & 53.5 \\
Kyrgyzstan & 32.0 & 35.5 \\
Tajikistan & 11.0 & 38.5 \\
Turmenistan & 5.5 & 15.0 \\
Uzbekistan & 29.0 & 112.5 \\
\hline
\end{tabular}

For 2003 , the President's Budget included $\$ 5.2$ billion for programs that were essential in pursuing the war on terrorism.

The President's use of aid in fighting terrorism was reaffirmed by Senate Resolution 204 in early February 2002. This resolution expressed the sense of the Senate regarding the importance of United States foreign assistance programs as a diplomatic tool for fighting global terrorism and promoting United States Security interests.

In this resolution the Senate noted that:

(1) United States foreign assistance programs should play an increased role in the global fight against terrorism to complement the natural security objectives of the United States;

(2) The United States should lead coordinated international efforts to provide increased financial assistance to countries with impoverished and disadvantaged populations that are the breeding grounds for terrorism;

(3) Consistent with United States foreign policy, economic incentives should be used to end state support or tolerance for terrorism; and

(4) The United States Agency for International Development and the Department of Agriculture should substantially increase humanitarian, economic development, and agricultural assistance to foster international peace and stability and the promotion of human rights.

In short, the US foreign assistance is enjoying a new lease on life as it is being looked upon by the Administration as an effective, highly visible tool in the early days of the anti-terrorism campaign. 
Clearly, the Administration and Congress feel that aid has the potential to strengthen economic and political stäbility of those governments that cooperate with Washington while responding to humanitarian needs.

Most of the pieces of the initial aid campaign were in place within the crucial 10 weeks after September 11 US officials then started looking to the next phase, which is likely to last much longer and be much more expensive. The reconstruction plan for Afghanistan alone will more than likely cost anywhere from $\$ 6$ to $\$ 10$ billion. Implementation will take years to complete.

\section{Medium Term Aid Strategy for Pakistan}

Focusing on Pakistan, US medium term assistance could conceivably take a number of forms: (1) increased general aid for budgetary support for anti-poverty programs; (2) additional debt relief - this could involve outright debt forgiveness as well as a restructuring of much of Pakistan's short term foreign obligations; (3) special access for Pakistan to the US market for textiles - using a long-term schedule expanding Pakistan's share of the US import market; (4) a long. term US aid commitment for strengthening governance and institutional change. (5) educational assistance, and (6) resumption of a long term military assistance to Pakistan.

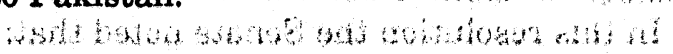

as Increased aid for anti-poverty programs, debt relief; and expanded military assistance for Pakistan are obvious areas on which the United States could focus, Less apparent, but perhaps even more important are our actions in two key areas educational reform and governance/institutional strengthening As discussed below, one thing both areas have in common is that, albeit in somewhat different ways, they are fertile breeding grounds for discontent and antiAmericanism. The following section focuses on what the United States might do to facilitate educational reform in Pakistan.

\section{Educational System}

One of the unique characteristics of the Pakistani educational system is the reliance on religious schools commonly known as Madrassahs. Historically these schools were founded as centres of learning for the next generation of Islamic scholars and clerics. As Singer (2001) notes, however, during the 1980s the Madrassah system. changed significantly. First, as part of its Islamization policy the Zia regime stepped up funding for the schools. Funds were dispersed at the local level to institutions deemed worthy of support by religious 
leaders, creating new incentives for opening religious schools. At the same time, the war in Afghanistan produced millions of refugees and the radicalism of a jihad movement.

Today, the schools are funded both by private donations from Middle Eastern countries and by the "zakat," a 2.5 percent tax collected by the Pakistani government from the bank accounts of Sunni Muslims once a year. The tax results in millions of dollars each year are directed to the schools. Foreign donations come mainly from rich individuals and Islamic charities in Saudi Arabia and the Gulf States.

A major reason for the popularity of the Madrassahs in Pakistan is that the country's public school system is in a shambles, and many families cannot afford the small fees that are charged. Madrassahs offer an attractive alternative: free education, free meals, free schoolbooks and even in some cases a stipend. While the exact numbers are unobtainable, estimates are that over a million and a half students study at more than 10,000 of these schools.

A number - probably a significant fraction - of these schools have built extremely close ties with radical militant groups. In this capacity they have increasingly played a critical role in sustaining the international terrorist network. In addition to their role in terrorism, the schools are a concern because of their non-technical, non-scientific curriculum. Many teach only religious subjects to their students, focusing on rote memorization of Arabic texts. In essence they are producing a generation of students unlikely to play a productive role in creating the type of modern dynamic economy necessary to reduce the country's grinding poverty.

\section{Educational Reform}

For its part the government is trying to revamp the country's school system, together with weeding out extremist Islamic educators. To this end, on June 19, 2002 the federal cabinet approved the Madrassah Registration Ordinance 2002, in force immediately, to regulate religious schools by bringing them under the formal educational system of the country. According to the ordinance, Madrassahs must register with the Pakistan Madrassah Education Board and the respective Provincial Madrassah Education Boards. A key aspect of the Ordinance is that unregistered Madrassahs will be prohibited from receiving Zakat funds, financial assistance, grants, donations or other benefits from the federal government or provincial governments. Madrassahs violating the Ordinance risk closure or a fine or both. 
The government is also trying to persuade the schools to teach science, mathematics, English and Urdu. This would provide students with the option, now usually lacking, of eventually enrolling in professional schools. The government has gone so far as to suggest that Madrassahs would receive government aid only if they begin providing what could be termed a "modern education".

According to the Ordinance every registered Madrassah is to maintain accounts and submit an annual report to their provincial education board. A registered Madrassah must not receive any grant, donation or aid from any foreign sources, or allow admission to foreign students or make appointment of teachers without a valid visa and a "No Objection Certificate" from the Interior Ministry.

The country's Madrassah plan is ambitious and very necessary. But by itself it will take years before the effects start to show. It is already apparent that change will not come soon to the Madrassahs. Not only are many religious groups violently opposed to any government interference, but the Ordinance is not compulsory. In practice, because of pressure from the clergy, the only penalty for not registering a Madrassah is that it will not be eligible to receive any government funding. Even this limited incentive is undercut by the fact that most of the schools receive little or no government funding to begin with. In August of 2002 after intensive lobbying by clergy leaders, the Musharraf Administration has pledged to water down the Ordinance.

Given the limited reforms likely in the Madrassahs in the near future, the United States and other donor countries should seriously consider using foreign aid and assistance to facilitate educational reform in Pakistan. As a start, the United States provided nearly $\$ 35$ million in 2002 to bolster the country's state school system. Now, the critical questions involve the most effective and efficient ways to proceed.

Singer has explored several of the options that might be worth considering. Logically, the United States could help the Pakistani government with one or more of the following options:

- Developing a public Madrassah system as an alternative to the current private Madrassahs.

- Developing a secular public education system that provides Pakistani families with a superior alternative to the Madrassahs.

- Developing alternatives and supplements outside the formal educational system 
- Obtaining educational aid from a variety of international sources.

Option 1, given the country's limited supply of educational facilities and qualified teachers, might appear to be an attractive short term solution. As Singer notes, publicly managed Madrassahs exist throughout the Middle East, teaching the tenets of Islam, but also providing a more modern curriculum. The United States could help in this effort, but should do nothing to imply direct American influence over the schools, which would discredit their Muslim credentials. Here, US aid should focus mainly on providing various educational materials and supplies. A major problem is that the schools would be hard to monitor for performance, and given the constraints on the role that the United States could play here, this may not be the best avenue through which to focus US efforts.

Option 2 would definitely entail considerable US aid and assistance. However, rough cost calculations indicate that this might be a promising option. Estimates are that the United States could build a school for several hundred children for $\$ 60,000$ and operate it for $\$ 10,000$ a year. This would appear to be an extremely cost effective alternative.

A final alternative noted by Singer, Option 3, would largely involve expanded American sponsorship of technical schools and other centers of learning within Pakistan. No doubt this would be a popular alternative for many students. As the government's economic reforms begin to bear fruit the demand for trained and skilled graduates will grow rapidly. More importantly, without a steady stream of qualified graduates, the country would have a hard time restoring growth in the $5-6 \%$ per annum range.

With regard to Option 4, many other international organizations are prepared to assist Pakistan's attempts at improving public education. The problem is that often the country does not meet all the conditions to qualify for this assistance. For example, the World Bank has recently named Pakistan and 22 other developing nations in Asia, Africa and Latin America to spearhead a campaign to educate all children by 2015. Unfortunately Pakistan, together with India, Bangladesh, the Democratic Republic of the Congo and Nigeria, currently falls short of the Bank's minimum criteria for receiving financial aid. The Bank has set two requirements for countries seeking financing: they must have a fully developed "poverty reduction strategy"; and they must be effectively implementing àn education plan 
that donor nations have agreed to. As part of its relationship with the IMF, Pakistan currently has a poverty reduction strategy in place. The US contribution could be useful in helping the Pakistani government develop a comprehensive educational plan that could draw financing not just from the World Bank but also from other international agencies and NGOs.

Educational reform will be one of Pakistan's most important challenges in the months and years ahead. Fortunately, the country has a number of viable options for moving away from the current dysfunctional system. Pakistan's progress in this area may be the most critical determinant of whether the country becomes a moderate, progressive nation joining the world community, or whether it descends into increased poverty, isolation, and instability.

\section{Longer Term Aid Strategy for Pakistan}

Clearly the Madrassahs are a breeding ground of militant Islam in Pakistan making educational assistance a top priority. With regard to other types of aid for Pakistan, the situation is not as obvious. Burki (2002) notes that the important question is not what kind of presence Al Qaeda has established in Pakistan. 'The real issue is how some segments of society can be weaned away from the type of thinking represented by Al Qaeda. Unless that is done, Pakistan will not be able to achieve either economic or political stability.' At issue then is on what objectives should aid be focused? Does terrorism breed in an environment of dire poverty as is now quite prevalent in Pakistan? Or is it more likely to take hold in an environment of dashed expectations and limited opportunity of economic success for not only the common man, but the educated as well ? - an environment that characterizes the plight of many Pakistanis.

\section{Root Causes of Terrorism}

As for the underlying causes of terrorism, initial post-9/11 speculation focused on poverty and low educational attainment as critical elements. With time and more rigorous research a different picture has emerged. Krueger and Maleckova's (2002) detailed and in-depth review of the evidence, on the other hand, provides little reason for optimism that a reduction in poverty or an increase in educational attainment, by themselves, would meaningfully reduce international terrorism. Their main finding is that any connection between poverty, low educational attainment, and terrorism is indirect, complicatêd, and probably quite weak. Instead of viewing terrorism as a direct 
response to low market opportunities or ignorance, they suggest it is more accurately viewed as a response to political conditions and longstanding feelings (either perceived or real) of indignity and frustration.

This finding is consistent with a recent United Nations Association of the National Capital Area (UNANCA) which notes that al Qaeda leaders and the September 11 participants were also affected by the following factors:

1. Widespread feelings of humiliation and decline from past high achievements of Islam throughout the Arab countries.

2. Broad acceptance throughout the Middle East of the fundamentalist message that the reason for the plight of Middle Eastern countries is that they and their governments have reverted to pre-Islamic barbarism by falling away from the original principles of Islam.

3. Despair over sagging economies, high unemployment, poor education, and low technological and scientific achievement in Middle Eastern countries.

4. Hatred for ineffective, often corrupt, authoritarian, predominantly secular Middle Eastern governments, which pay lip service to the tenets of fundamentalist Islam, but are reluctant to put it into practice and often suppress fundamentalists by force.

5. Resentment against the United States for its highly visible, seemingly unquestioning support of some Arab governments.

6. Resentment against the USA and other Western countries for their claimed arrogance, secular materialism, history of colonial domination, political manipulation and interference in support of corrupt governments; for civilian casualties from US-UK military actions and Western economic sanctions in Iraq; and also for Western material success while Islamic governments fail.

7. Resentment against the USA for its support of Israel; resentment against Israel itself for its treatment of the Palestinians, for repeatedly defeating Arab armies and clearly demonstrating the inferiority of these armies, and for prospering far more than Arab countries.

\section{Economic Constraints}

Clearly many of these frustrations are playing out in Pakistan as many in that country have grown frustrated with the inability of the country's political leaders to build and maintain an economic system capable of sustaining respectable rates of economic growth. Historically, Pakistan grew faster than the South Asia average by an 
average of two percent in the $1960 \mathrm{~s}$ and $1970 \mathrm{~s}$, and at similar rates through the 1980s. Since 1993, Pakistan's growth has been below the regional average. In contrast, after starting slowly, growth in South Asia as a whole has been steadily accelerating for the four decades (Looney, 2001). In short, with the exception of a spurt in the $1980 \mathrm{~s}$, trends in growth in Pakistan have been steadily slowing from initially very high levels since the 1960s. At that time, many observers thought the country had taken off in the Rostow (1960) sense - industrialization was proceeding rapidly and the agricultural sector was experiencing a revolution in productivity gains. To a lesser extent, the 1980 s also represents a failed take-off.

William Easterly (2001) has termed Pakistan's experience as an illustration of a 'growth without development' phenomena. Easterly's main point is that the country's poor social indicators have lowered the productive potential economy and its ability to service its high debt. His observations are suggestive of possible explanations for Pakistan's failed take-offs, together with a fairly respectable overall growth rate of $5.4 \%$ over the $1961-2001$ period. It may be that a certain degree of development and growth was attainable with skilled managerial elite and unskilled workers, but over time, this strategy ran into diminishing returns, as human capital did not grow at the same rate as the other factors. While not definitive, this explanation is consistent with the slowdown in growth from the late 1980 s to the present.

Along these lines Shahid Husain (2001) has attributed the country's inability to sustain high growth to the following factors:

- An increase in the role of the state has coincided with a decline in governance.

- Non-competitive regimes politically and economically have resulted in rampant corruption and stagnation - the subyersion of competitiveness was the central feature of Pakistani governments.

- There has been a continuous redistribution of wealth in favour of privileged groups.

- A hard crust of economic monopoly has stifled new growth and creativity.

- An erosion in the provision of public services has resulted in a decline of the public's trust in government which is seen as predatory. This, in turn, is linked to non-payment of taxes, the corruption in tax administration, and the massive increase in borrowing. 
- The quality of the civil bureaucracy is falling rapidly. A majority of civil servants are not even paid a living wage and this is tantamount to an incentive to corruption.

- The irrelevance of the state in the lives of the people is exemplified by the total breakdown of law and order.

- The inability and unwillingness of the state to discharge its social services has meant a vacuum in social services. Pakistan's literacy rate has remained almost unchanged since Independence. The dependence on madrassahs is hence understandable.

From this, Hasain correctly concludes that little economic progress, let alone a take-off, can be made in the country until the government is able to re-establish its presence in the political, social, and economic lives of the people.

These patterns of failed take-off, failed government economic management and long run decline suggest that Pakistan is a classic example of a country fulfilling Krueger and Maleckova's description of a terrorist breeding ground. Clearly, large segments of the population have become weary and frustrated with the country's lack of economic progress, especially now that the Indian economy is pulling away with a much higher and accelerating rate of growth.

\section{Implications for United States Aid}

While the analysis above makes a strong case for Pakistan's terrorism problems being an outgrowth of widespread frustration over the country's economic failures and lack of opportunity and economic freedom (Looney, 1997), the two other commonly cited sources of terrorism, poverty and the militant Islam, noted in the section on education are no doubt also contributing factors and need to be addressed. However, it is unlikely that focusing on them exclusively will significantly reduce the seeming attractiveness of terrorism.

Instead, assistance needs to focus on the policy changes and institution-building needed to put the economy on a high growth path. Here, United States aid can make a significant contribution by assisting the government attack the root causes of terrorism - those elements that define the diversionary economy and currently suppress economic freedom. In targeting these areas (Figure 1), contributions (dotted lines in Figure 1) toward reducing poverty and the numbers of Islamic militants would occur simultaneously. 
Figure 1: Sources of Terrorism in Pakistan: Implications for

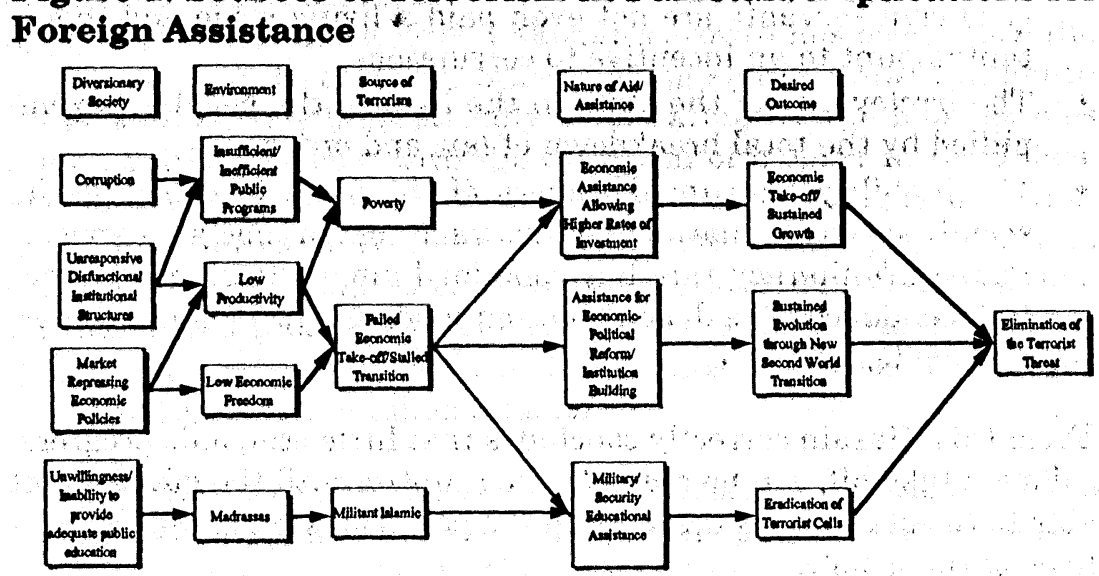

Ordinary aid towards institution building, anti-corruption and the like might face strong domestic obstacles. However, in Pakistan's case, the Musharraf anti-corruption and institutional strengthening reforms are already in place and are appropriate for the war against terrorism - they simply need to be adequately funded and implemented. As a result, the United States would not be perceived as trying to impose a foreign set of institutions on the country. The overall guideline for allocating assistance should be simple and direct: is this program assisting the country in moving towards a choice based system?

This approach is also consistent with the objectives laid out in the country's new Five Year Plan to raise the GDP growth rate to 6 percent by June 30, 2005 (Naqvi, 2003). To achieve this the government has targeted six key areas: (1) political stability; (2) regional stability; (3) a better law and order situation; (4) the continuance of fiscal responsibility - tight control over budget deficits; (5) economic policies have to remain consistent and transparent; and (6) the structural reforms program must actually be adhered to and completed.

The key remaining issue surrounds the type of assistance - should it be in the form of aid, with a stipulated rate of interest or an outright grant. For individual projects, the logic is straightforward.

Grants are a gift with strings attached. Counter to the usual policy of lending blanket sums for indeterminate government plans, grants are usually project-linked and executed under competitive bid. For the easily quantified basic needs that improve the quality of life and 
are the preconditions for economic growth - health, primary education, and water sanitation - the grant system would count by independent audit and pay for output: numbers of babies vaccinated, children that can read and water and sewer services delivered to villages. No results: no funds expended. No funds are to be diverted to off-shore bank accounts, vanity projects or private jets.

The Bush Administration is already moving in these directions. In addition to its growing preference for grants, the President's recent speech at the United Nations March 2002 conference on financing for development in Monterrey, Mexico, emphasized the importance of sound economic policies and the encouragement of enterprise. He promised that countries which adopt the right policies will get more aid from the United States.

For the type of institutional loans under consideration here, the situation is more complicated because output is harder to measure and there would be no real scope for competitive bids to provide the contracted outputs. Traditional aid often failed in these situations because there was no means to enforce penalties for failure to perform and often no real incentives on the part of the recipient country to continue or even start the reform process. One alternative in the current context would be to make short-term concessional loans conditional on institutional reform. Progress (as judged by annual independent audit) could be rewarded with an extension of the cocessional loan. Poor implementation would trigger immediate repayment. Because the grant element of a concessional loan increases as the loan's maturity increases, the Pakistani government would have a real incentive to follow through to successful implementation. As an added incentive a clause could be included converting the concessional loan into a grant upon successful completion of the reform.

\section{Conclusions}

Clearly military actions together with foreign aid/grant programs provide an effective start to abating the Al Queda threat. It is clear, however, that the ultimate defeat of Al Queda and similar groups will require the elimination of the appeal of terrorist motivation to potential adherents. Fighting the sources of terrorist motivation will call for comprehensive international cooperation in support of long-term political, economic and social programs in many Middle Eastern countries and Pakistan aimed at affecting and modifying the values and convictions which have motivated the suicide bombers and at drying up the support for al Qaeda and similar organizations. Aid can play 
an effective role here, but will require the restructuring of traditional assistance programs to deal not only with poverty and growth but with a whole set of broader issues.

\section{References}

Burki, Shahid Javed, (2002) Terrorism \& development. Dawn, May 21. http://www.dawn.com/2002/05/21/op.htm

Easterly, W. (2001) The Political Economy of Growth Without Development: A Case Study of Pakistan, Washington: World Bank, June.

Husain, S. (2001) Pakistan's Future and U.S. Policy Options, Working Group Meeting on Economic Revival (Washington, CSIS. November 27.

http://www.csis.org/saprog/011127PKevent.pdf

Krueger, A. B. \& Maleckova, J. (2002) Education, Poverty, Political Violence and Terrorism: Is there a Causal Connection, Cambridge, Mass: National Bureau of Economic Research.

Looney, R. (2002) Pakistan's economy: Achievements, progress, constraints and progress in H. Malik (ed.), Pakistan: Founders' Aspirations and Today's Realities. Oxford: Oxford University Press, p.235. http.//web.nps.navy.mil/ $\sim$ relooney/Villanova.pdf

Looney, R. (1997) Pakistan's progress towards economic freedom Contemporary South Asia 6, 1) http://web,nps.navy.mil/ relooney/ RelCSA2.pdf

Naqvi, M.B. (2003) The new Five Year Plan, The News, January 20.

Rostow, W.W. (1960) The Stages of Economic Growth: A Non-Communist Manifesto London: Cambridge University Press.

Singer, P.W. (2001) Pakistan's Madrassahs: Ensuring a System of Education not Jihad Brookings, November .

UNANCA (2002) The Peace and Security Task Force Report to UNANCA Board of Directors: Fighting an Effective War Against Terrorism, March 19. 